J. Dairy Sci. 98:7635-7639

http://dx.doi.org/10.3168/jds.2015-9388

(c) American Dairy Science Association ${ }^{\circledR}, 2015$.

\title{
Short communication: Potential of Fresco-style cheese whey as a source of protein fractions with antioxidant and angiotensin-I-converting enzyme inhibitory activities
}

\author{
S. Tarango-Hernández, ${ }^{*}$ A. D. Alarcón-Rojo, ${ }^{*}$ M. Robles-Sánchez,† N. Gutiérrez-Méndez,ł \\ and J. C. Rodríguez-Figueroa*1 \\ *Departamento de Tecnología de Alimentos de Origen Animal, Facultad de Zootecnia y Ecología, UACH, Fco. R. Almada km 1, 31453 Chihuahua, \\ Chihuahua, México \\ †Departamento de Investigación y Posgrado en Alimentos, Universidad de Sonora, Blvd. Luis Encinas y Rosales s/n, Col. Centro, \\ 83000 Hermosillo, Sonora, México \\ ‡Departamento de Ciencia y Tecnología de Alimentos, Facultad de Ciencias Químicas, Universidad Autónoma de Chihuahua (UACH), \\ Campus Universitario \#2, 31125 Chihuahua, Chihuahua, México
}

\section{ABSTRACT}

Recently, traditional Mexican Fresco-style cheese production has been increasing, and the volume of cheese whey generated represents a problem. In this study, we investigated the chemical composition of Fresco-style cheese wheys and their potential as a source of protein fractions with antioxidant and angiotensin-I-converting enzyme (ACE)-inhibitory activities. Three samples from Fresco, Panela, and Ranchero cheeses whey were physicochemically characterized. Water-soluble extracts were fractionated to obtain whey fractions with different molecular weights: $10-5,5-3,3-1$ and $<1 \mathrm{kDa}$. The results indicated differences in the lactose, protein, ash, and dry matter contents (\% wt/wt) in the different Fresco-style cheese wheys. All whey fractions had antioxidant and ACE-inhibitory activities. The 10-5 $\mathrm{kDa}$ whey fraction of Ranchero cheese had the highest Trolox equivalent antioxidant capacity $(0.62 \pm 0.00$ $\mathrm{m} M$ ), and the $3-1 \mathrm{kDa}$ Panela and Fresco cheese whey fractions showed the highest ACE-inhibitory activity $(0.57 \pm 0.02$ and $0.59 \pm 0.04 \mu \mathrm{g} / \mathrm{mL} 50 \%$-inhibitory concentration values, respectively). These results suggest that Fresco-style cheese wheys may be a source of protein fractions with bioactivity, and thus could be useful ingredients in the manufacture of functional foods with increased nutritional value.

Key words: Fresco-style cheese whey, antioxidant activity, angiotensin-I-converting enzyme-inhibitory activity, chemical composition

Received January 27, 2015.

Accepted July 25, 2015.

${ }^{1}$ Corresponding author: jfigueroa@uach.mx or jcsolar@gmail.com

\section{Short Communication}

Hispanic-style cheese production has been increasing in recent years. Indeed, according to the USDA, Hispanic cheese production increased by $7.9 \%$ between March 2013 and February 2014 (USDA-NASS, 2014). In Mexico, cheese production grew by $8.9 \%$ between November 2013 and November 2014, with Frescostyle cheeses representing $64 \%$ of the total production $(312,082$ t; SIAP-SAGARPA, 2014). However, it has been reported that the manufacture of $1 \mathrm{~kg}$ of cheese generates $9 \mathrm{~kg}$ of whey (Prazeres et al., 2012). Thus, the volume of whey generated from manufacture of Fresco-style cheeses was estimated to be $1,797,000 \mathrm{t}$ in 2014, which has been difficult to solve in terms of waste management. Cheese whey is considered a major environmental pollutant because of its high biological (27-60 g/L) and chemical (50-102 g/L) oxygen demands due to the presence of organic matter (Carvalho et al., 2013). The chemical composition of several types of cheese whey has been summarized (Siso, 1996; Pintado et al., 2001), but scarce information is available about Fresco-style cheese wheys. Studies have demonstrated that cheese whey proteins may have beneficial biological and nutritional properties for health promotion and disease prevention (Erdmann et al., 2008). In fact, the AA present in these proteins, such as tyrosine and cysteine, may exert free radical-scavenging activity (Pihlanto, 2006). Moreover, the hydrolysates from bovine whey protein concentrate are able to inhibit angiotensin-I-converting enzyme (ACE; Tavares et al., 2011). For many years, ACE has been a major physiological target in the development of antihypertensive drugs and natural products (Udenigwe and Mohan, 2014). Hafeez et al. (2014) suggested that fractionation of whey proteins might be a strategy to increase their bioactivity. Therefore, in the present study, we investigated the chemical composition of Fresco-style cheese 
wheys, and explored their potential as a source of protein fractions with antioxidant and ACE-inhibitory activities.

All cheeses were made in the same plant following traditional cheese-making procedures (Figure 1). Whey samples $(2 \mathrm{~L})$ were obtained from rennet-coagulated Fresco, Panela, and Ranchero cheeses manufactured in Chihuahua, Mexico, from each vat at 3 different times during February and March 2013. Fresco, Panela, and Ranchero cheeses are all considered Fresco-style cheeses; Fresco and Panela cheeses have significantly more moisture than Ranchero cheese (our unpublished data). Whey samples were immediately divided in half upon reaching the laboratory, with one half being used for chemical composition analyses and the other for fractionation.

The chemical composition of liquid cheese whey samples was evaluated in terms of moisture (AOAC International, 1995; method 925.23), ash (AOAC International, 1995; method 945.46), and fat (Norma Oficial Mexicana, 2012) contents. Protein content was determined by Bradford method (Bradford, 1976). Bovine serum albumin was used as standard. Lactose was estimated as DM minus the sum of protein, ash, and fat expressed as percentages (wt/wt). The $\mathrm{pH}$ was determined using a Versa star $91 \mathrm{pH}$ meter (Orion, Singapore). All analyses were done in triplicate.

The liquid cheese whey samples were centrifuged twice at $6,000 \times g$ for $30 \mathrm{~min}$ at $10^{\circ} \mathrm{C}$ (Avanti J-26, Beckman Coulter Inc., Fullerton, CA). Fat was removed from the samples. Then, the cheese whey water-soluble extracts were fractionated using $10-, 5-, 3-$, and $1-\mathrm{kDa}$ membranes (Ultracel Millipore, Bedford, MA) with an Amicon system (Millipore). The 10-5, 5-3, 3-1, and $<1$ $\mathrm{kDa}$ cheese whey fractions were frozen at $-20^{\circ} \mathrm{C}$ until further analyses.

Antioxidant activity was measured as Trolox (6-hydroxy-2,5,7,8-tetramethylchromane-2-carboxylic acid)equivalent antioxidant capacity (TEAC). This method is based on scavenging the cation radical 2,2'-azino-bis (3-ethylbenzothiazoline)-6-sulfonic acid $\left(\right.$ ABTS $^{\bullet+}$; Sigma-Aldrich, St. Louis, MO; Re et al., 1999). The ABTS stock solution $(7.0 \mathrm{~m} M)$ was oxidized by adding potassium persulfate (Sigma Aldrich; $2.45 \mathrm{mM}$ ) buffer. The mixture was kept at room temperature in the dark for 12 to $16 \mathrm{~h}$ to obtain $\mathrm{ABTS}^{\bullet+}$. Subsequently, it was diluted in ethanol $(99.9 \%)$ to yield an absorbance of 0.7 \pm 0.02 at $734 \mathrm{~nm}$. Trolox (Sigma Aldrich, Milwaukee, WI) or cheese whey fractions $(100 \mu \mathrm{L})$ were added to $2.9 \mathrm{~mL}$ of $\mathrm{ABTS}^{\circ}{ }^{+}$and reacted with their antioxidant

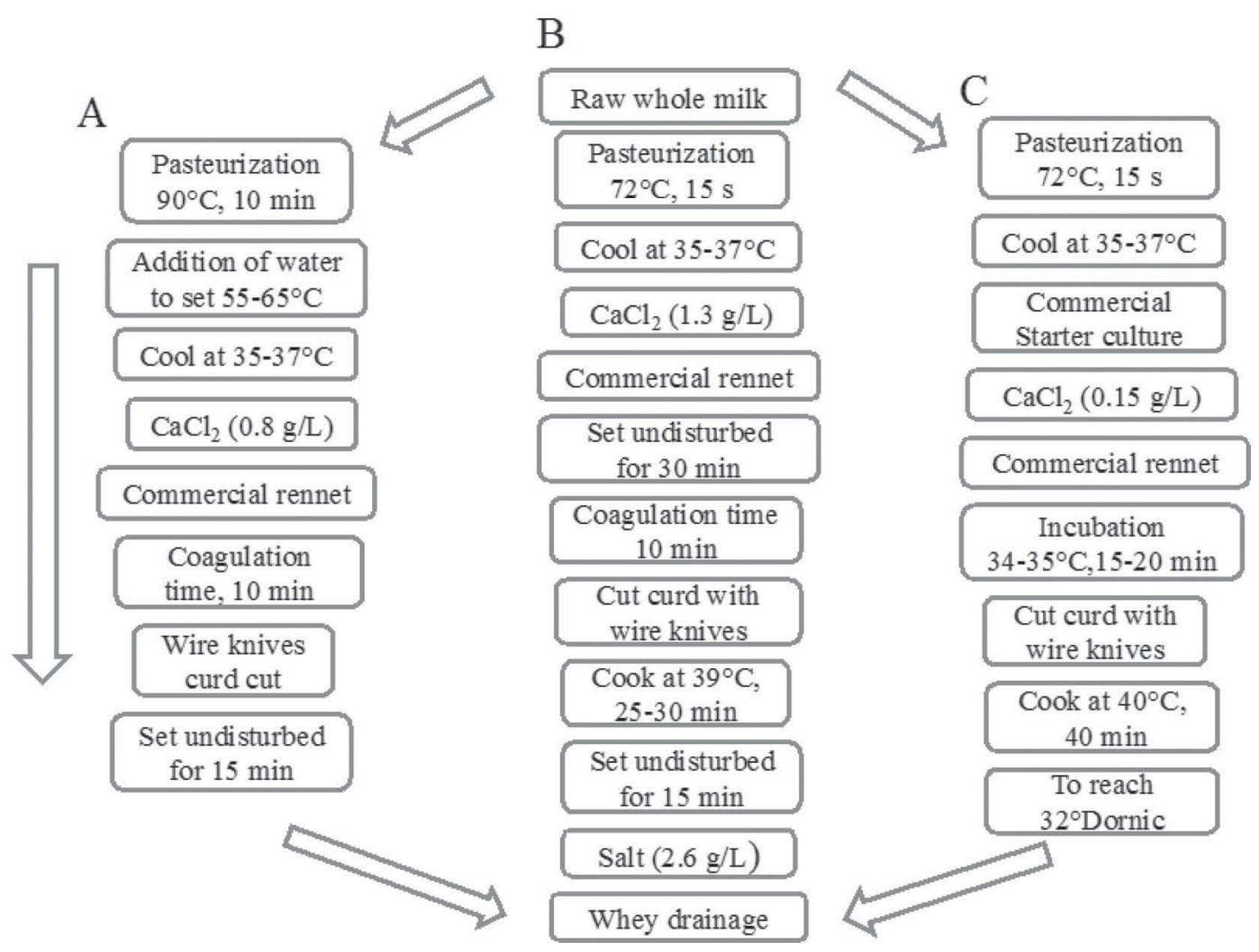

Figure 1. Fresco-style cheese-making scheme corresponding to whey sample collection from the manufacture of (A) Panela, (B) Fresco, and (C) Ranchero cheeses. 
peptides for $5 \mathrm{~min}$ at room temperature. Scavenging of $\mathrm{ABTS}^{\bullet+}$ was monitored spectrophotometrically (Cary 50 bio, Varian, Palo Alto, CA) based on decreases in absorbance. The solvent was used as the negative control. Each sample was evaluated in triplicate, and antioxidant capacity was calculated using a standard curve from 0.1 to $0.6 \mathrm{~m} M$ Trolox. The results were expressed as TEAC values.

The ACE-inhibitory activity was measured according to the method reported by $\mathrm{Wu}$ et al. (2002) and Ghassem et al. (2011), with some modifications. A cheese whey fraction $(50 \mu \mathrm{L})$ was added to $200 \mu \mathrm{L}$ of $2.5 \mathrm{mM}$ hippuryl-L-histidyl-L-leucine (HHL) substrate, which contained $50 \mathrm{~m} M$ Tris buffer and $300 \mathrm{~m} M \mathrm{NaCl}(\mathrm{pH}$ 8.3). This mixture was incubated at $37^{\circ} \mathrm{C}$ for $3 \mathrm{~min}$. A $20-\mu \mathrm{L}$ aliquot of $\mathrm{ACE}(0.1 \mathrm{U} / \mathrm{mL})$ was added to the mixture, which was vortexed, incubated at $37^{\circ} \mathrm{C}$ for 30 min, and shaken at $200 \mathrm{rpm}$. The amount of hippuric acid (HA) produced in the reaction was used to measure ACE-inhibitory activity. Finally, the reaction was stopped by adding $250 \mu \mathrm{L}$ of $1 \mathrm{M} \mathrm{HCl}$. All samples were filtered using a $0.22-\mu \mathrm{m}$ syringe filter (Spartan 30/0.2 RC, Whatman, Dassel, Germany). Separation of HA from HHL was performed using a reversed phase (RP)HPLC system equipped (UFLC-LC 20AD, Shimadzu, Columbia, MD) with an autosampler (SIL-20AHT), system controller (CBM-20A), binary solvent deliver pump system, and UV-Vis detector (SPD-20A). The samples were eluted on a Discovery $\mathrm{C}_{18}$ column (250 $\mathrm{mm} \times 4.6 \mathrm{~mm} ; 5-\mu \mathrm{m}$ particle size, Supelco, Bellefonte, PA). A $50-\mu \mathrm{L}$ sample was eluted using an isocratic program with 50:50 methanol:water containing 0.1\% (vol/vol) trifluoracetic acid. The flow rate was $0.4 \mathrm{~mL} /$ min and the absorbance was measured at $228 \mathrm{~nm}$. The RP-HPLC HA peak was integrated using LabSolutions LCMS Ver.5 software (Shimadzu), and HA was quantified using a standard curve. The ACE-inhibitory activity was calculated using the formula reported by Ghassem et al. (2011):

$$
\begin{gathered}
\text { ACE-inhibitory activity }(\%)= \\
(A-B) /(A-C) \times 100,
\end{gathered}
$$

where $A$ is the integrated area under the curve of the HA peak produced by $\mathrm{ACE}$ and the substrate, $B$ corresponds to the HA peak area with the peptide fraction, and $C$ is the HA peak area without ACE. The ACE-inhibitory activity was also expressed as the halfmaximal inhibitory concentration $\left(\mathbf{I} \mathbf{C}_{50}\right)$, defined as the peptide or protein concentration $(\mu \mathrm{g} / \mathrm{mL})$ in the cheese whey fraction required to inhibit $50 \%$ of ACE activity. The peptide content of the fractions was determined using the bicinchoninic acid assay (BCA kit, Sigma Aldrich). Bovine serum albumin was used as standard.
The $\mathrm{IC}_{50}$ values were estimated based on a linear regression using the peptide concentration related to the ACE-inhibitory activity.

The experiment was repeated 3 times with at least 3 replicates. The data were analyzed by one-way ANOVA between molecular weight fractions, as well as among the different Fresco-style cheese wheys. Significant differences between means were determined using the Tukey-Kramer test and considered significant when $P$ $<0.01$. All statistical analysis was performed using the NCSS 2007 statistical program (NCSS Inc., Kaysville, $\mathrm{UT})$.

Initially, we performed physicochemical characterizations of Fresco-style cheese whey samples, which may help to determine their alternative uses. Our findings showed relevant differences in the chemical composition of Fresco, Panela, and Ranchero cheese wheys; the results are summarized in Table 1. Significant differences $(P<0.01)$ were found in lactose, protein, ash, and DM contents (\% wt/wt). The Fresco and Ranchero cheese wheys had the highest DM values $(8.6 \pm 0.3 \%$ and $7.2 \pm 0.4 \%$, respectively). The highest ash percentage was observed in Fresco cheese whey (1.87\%), which may reflect the amount of $\mathrm{CaCl}_{2}(1.3 \mathrm{~g} / \mathrm{L})$ and salt $(2.6 \mathrm{~g} / \mathrm{L})$ added during the manufacturing process. Fresco and Ranchero cheese wheys had the highest $(P<0.01)$ protein content $(0.73 \pm 0.13 \%$ and $0.64 \pm$ $0.08 \%$, respectively). Panela cheese whey had the lowest $(P<0.01)$ contents of DM $(4.3 \pm 0.6 \%)$ and protein $(0.21 \pm 0.02 \%)$. The high percentage of water $(95.6$ $\pm 0.3 \%$ ) present in Panela cheese whey means that it is more expensive to concentrate its solids compared with Fresco and Ranchero cheese wheys. Previous studies included in the review published by Pintado et al. (2001) showed that Camembert and Cheddar cheeses whey had DM contents of 6.9 and $6.7 \%$, respectively, and that the chemical composition of Cheddar cheese whey comprised $0.5 \%$ ash, $4.9 \%$ lactose, $0.8 \%$ protein, and $0.5 \%$ fat (wt/wt). Indeed, Cheddar cheese whey is the main starting material for producing whey protein concentrate (WPC) and isolate (WPI) in the United States (Zhu and Damodaran, 2012). The chemical compositions of Cheddar and Ranchero cheese wheys were similar. We also found that Fresco cheese whey had a high lactose content $(5.7 \pm 0.3 \%)$. Therefore, according to our chemical composition analyses, Ranchero and Fresco cheeses whey could be concentrated and transformed into valuable ingredients for the food industry instead of being a potential environmental pollutant.

Antioxidant and ACE-inhibitory activities of Frescostyle cheese wheys were also investigated. All cheese whey fractions had antioxidant activity (Figure 2). This activity increased with the peptide molecular weight fraction (i.e., the $10-5 \mathrm{kDa}$ fraction in all cheese 
Table 1. Chemical composition of Fresco-style cheese wheys ${ }^{1}$

Chemical composition (\%, wt/wt)

\begin{tabular}{|c|c|c|c|c|c|c|}
\hline \multirow[b]{2}{*}{ Cheese whey } & \multirow[b]{2}{*}{$\mathrm{pH}$} & \\
\hline & & $\mathrm{DM}$ & Ash & Protein & Fat & Lactose \\
\hline Fresco & $5.0 \pm 0.4^{\mathrm{a}}$ & $8.6 \pm 0.3^{\mathrm{a}}$ & $1.9 \pm 0.1^{\mathrm{a}}$ & $0.73 \pm 0.13^{\mathrm{a}}$ & $0.31 \pm 0.10^{\mathrm{a}}$ & $5.7 \pm 0.3^{\mathrm{a}}$ \\
\hline Ranchero & $5.2 \pm 0.1^{\mathrm{a}}$ & $7.2 \pm 0.4^{\mathrm{a}}$ & $0.6 \pm 0.5^{\mathrm{b}}$ & $0.64 \pm 0.08^{\mathrm{a}}$ & $0.37 \pm 0.10^{\mathrm{a}}$ & $5.6 \pm 0.6^{\mathrm{a}}$ \\
\hline Panela & $5.9 \pm 0.4^{\mathrm{a}}$ & $4.3 \pm 0.6^{\mathrm{b}}$ & $0.5 \pm 0.8^{\mathrm{b}}$ & $0.21 \pm 0.02^{\mathrm{b}}$ & $0.12 \pm 0.03^{\mathrm{a}}$ & $3.5 \pm 0.6^{\mathrm{b}}$ \\
\hline
\end{tabular}

${ }^{a, b}$ Different superscript letters within a column indicate significant differences $(P<0.01)$.

${ }^{1}$ Data represent the mean values $\pm \mathrm{SD}(\mathrm{n}=3)$.

wheys had higher activity than the $<1 \mathrm{kDa}$ fraction). A previous study found a similar relationship between antioxidant activity and the size of water-soluble extract fractions (Moslehishad et al., 2013). We found that the maximum capacity for scavenging $\mathrm{ABTS}^{\bullet+}$ was obtained with the $10-5 \mathrm{kDa}$ cheese whey fraction. The Ranchero cheese whey fraction had the highest antioxidant value $(0.62 \pm 0.00 \mathrm{~m} M$ TEAC; $P<0.01)$, and the $3-1 \mathrm{kDa}$ Panela cheese whey fraction $(0.11 \pm$ $0.01 \mathrm{~m} M$ TEAC) had the lowest $(P<0.01)$ value. The presence of aromatic and hydrophobic AA residues in the peptide sequences is considered crucial for radical scavenging but peptide size may also have an important effect (Ajibola et al., 2011).

We also evaluated the ACE-inhibitory activity of Fresco-style cheese wheys. The ACE-inhibitory potency of cheese whey fractions was expressed as the $\mathrm{IC}_{50}$ value. In this study, all cheese whey fractions

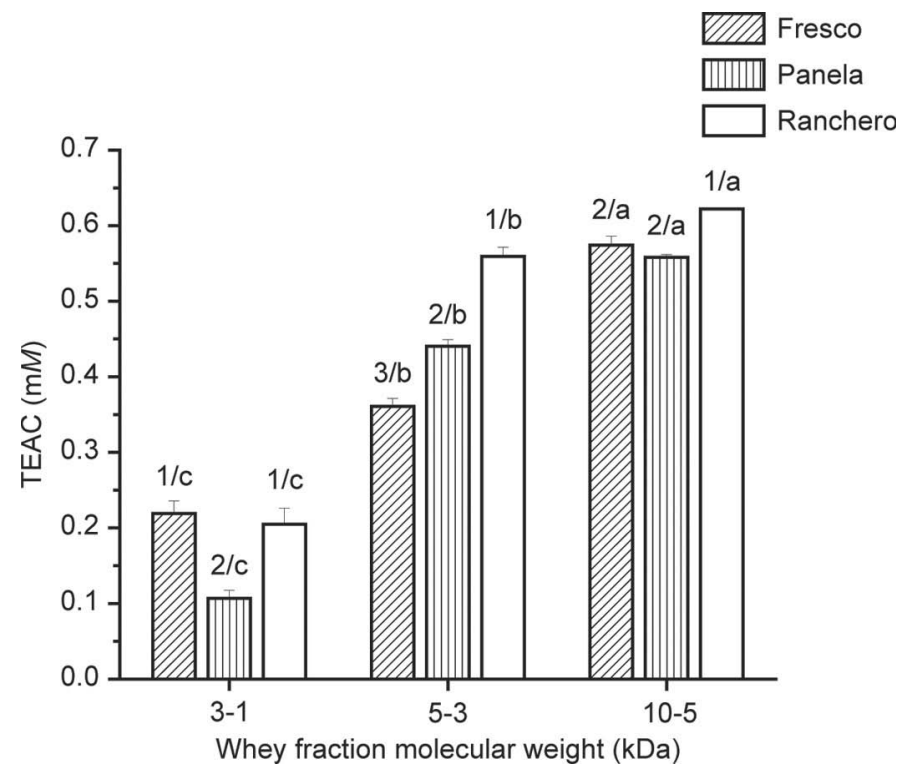

Figure 2. Antioxidant activity of Fresco-style cheese whey fractions. The data represent the Trolox equivalent antioxidant activity $($ TEAC, $\mathrm{m} M)$ mean values $\pm \mathrm{SD}(\mathrm{n}=3)$. Distinct numbers associated with each Fresco-style cheese whey for the same molecular weight fraction $(10-5,5-3,3-1$, and $<1 \mathrm{kDa}$ cheese whey fractions) and lowercase letters associated with the same cheese whey for each molecular weight fraction mean values indicate significant differences $(P<0.01)$. had ACE-inhibitory activity, and $\mathrm{IC}_{50}$ values ranged from $0.57 \pm 0.02$ to $4.52 \pm 1.2 \mu \mathrm{g} / \mathrm{mL}$ (Figure 3 ). We found remarkable differences between the Fresco-style cheese wheys, as well as between the different molecular weight fractions. The $3-1 \mathrm{kDa}$ Panela and Fresco cheese whey fractions had the highest $(P<0.01)$ ACEinhibitory activity $(0.57 \pm 0.02$ and $0.59 \pm 0.04 \mu \mathrm{g} /$ $\mathrm{mL}$, respectively), whereas the $5-3 \mathrm{kDa}$ Panela cheese whey fraction $(1.21 \pm 0.11 \mu \mathrm{g} / \mathrm{mL})$ had the lowest $(P$ $<0.01$ ). Miguel et al. (2009) demonstrated that a $<3$ $\mathrm{kDa}$ hydrolyzed bovine casein fraction had 10 times more ACE-inhibitory activity than the corresponding unfractionated whey. In contrast, we found no significant difference $(P>0.01)$ between whey fractions from Ranchero cheese. Few studies have evaluated the ACEinhibitory activity of Fresco-style cheese wheys. Paul and Van Hekken (2011) investigated ACE-inhibitory activity in Queso Fresco manufactured with pasteurized milk, where 2 water-soluble extracts inhibited ACE by 93.1 and 50.8\%. Moreover, Torres-Llanez et al. (2011) evaluated the ACE-inhibitory activity in Mexican Fresco cheese inoculated with native lactic acid bacteria. They found that the $\mathrm{IC}_{50}$ values of the $<3$-kDa watersoluble extracts ranged from 5.2 to $10.7 \mu \mathrm{g} / \mathrm{mL}$. These results suggest that differences in ACE inhibition may be related to peptide sequences present in the protein sources in each molecular weight fraction. In a previous study, we found that a $<3-\mathrm{kDa}$ RP-HPLC peptide fraction obtained from fermented milk could inhibit $\mathrm{ACE}$ activity. It had an $\mathrm{IC}_{50}$ value of $0.076 \pm 0.004 \mu \mathrm{g} /$ $\mathrm{mL}$ and most of the peptide sequences included in the fraction were derived from $\alpha$-lactalbumin (RodríguezFigueroa et al., 2012).

In summary, Fresco-style cheese manufacturing generates considerable amounts of whey, a potential environmental pollutant; therefore, it is important to explore alternative uses for this whey. We characterized the physicochemical composition of Panela, Ranchero, and Fresco cheese wheys and found that the chemical composition of Ranchero cheese was similar to that of Cheddar cheese whey. Antioxidant and ACE-inhibitory activities of Fresco-style cheeses whey were also evaluated. All cheese whey fractions had TEAC and ACEinhibitory activities. Moreover, molecular weight frac- 


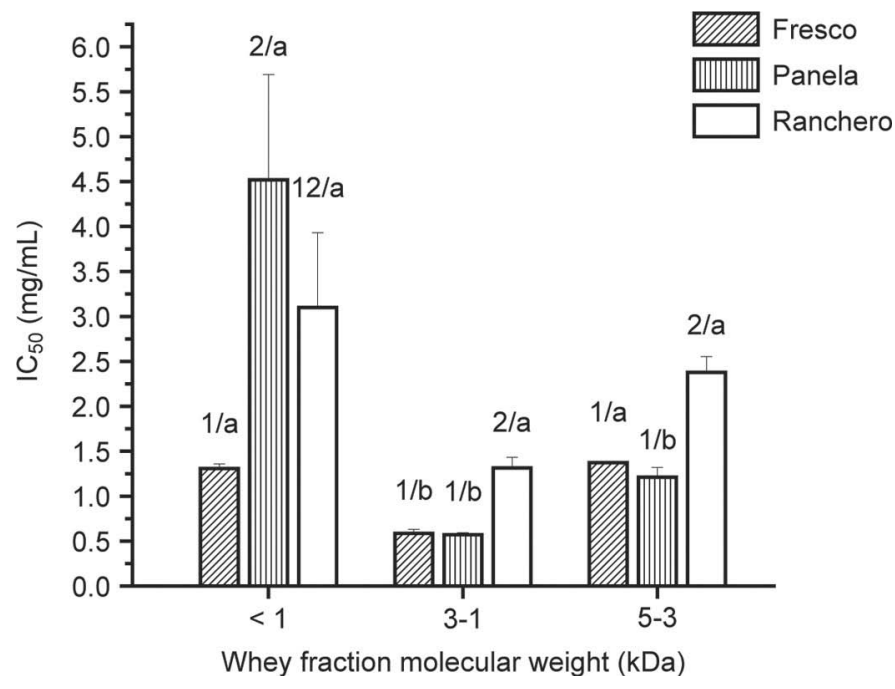

Figure 3. Angiotensin I-converting enzyme (ACE)-inhibitory activity of Fresco-style cheese whey fractions. The data represent the ACE-inhibitory activity (the $\mathrm{IC}_{50}$ value represents the peptide or protein concentration present in the cheese whey fractions required to inhibit $50 \%$ of the $\mathrm{ACE}$ activity, $\mathrm{mg} / \mathrm{mL})$ mean values $\pm \mathrm{SD}(\mathrm{n}=3)$. Distinct numbers $(1,2)$ associated with each Fresco-style cheese whey for the same molecular weight fraction $(10-5,5-3,3-1$, and $<1 \mathrm{kDa}$ cheese whey fractions) and lowercase letters ( $\mathrm{a}, \mathrm{b})$ associated with the same cheese whey for each molecular weight fraction mean values indicate significant differences $(P<0.01)$.

tionation allowed us to identify those fractions with the highest activities. Findings from this study establish that Fresco-style cheese whey fractions may be useful ingredients in the manufacture of functional foods and foods with increased nutritional value.

\section{ACKNOWLEDGMENTS}

We thank the Mexican Science and Technology Council (CONACYT) and the Secretary of Public Education for financing this study (projects INFRA-2012.01-187398 and PROMEP/103.5/12/3923), as well as Martha Campos Cañas for her support in the Laboratory of Food Biotechnology.

\section{REFERENCES}

Ajibola, C. F., J. B. Fashakin, T. N. Fagbemi, and R. E. Aluko. 2011. Effect of peptide size on antioxidant properties of African yam bean seed (Sphenostylis stenocarpa) protein hydrolysate fractions. Int. J. Mol. Sci. 12:6685-6702.

AOAC International. 1995. Official Methods of Analysis. 16th ed. AOAC International, Washington, D.C.

Bradford, M. M. 1976. A rapid and sensitive method for the quantitation of microgram quantities of protein utilizing the principle of protein-dying binding. Anal. Biochem. 72:248-254.

Carvalho, F., A. R. Prazeres, and J. Rivas. 2013. Cheese whey wastewater: Characterization and treatment. Sci. Total Environ. 445446:385-396.

Erdmann, K., B. W. Y. Cheng, and H. Schröder. 2008. The possible roles of food-derived bioactive peptides in reducing the risk of cardiovascular disease. J. Nutr. Biochem. 19:643-654.
Ghassem, M., K. Arihara, A. Salam Babji, M. Said, and S. Ibrahim. 2011. Purification and identification of ACE inhibitory peptides from Haruan (Channa striatus) myofibrillar protein hydrolysate using HPLC-ESI-TOF MS/MS. Food Chem. 129:1770-1777.

Hafeez, Z., C. Cakir-Kiefer, E. Roux, C. Perrin, L. Miclo, and A. DaryMourot. 2014. Strategies of producing bioactive peptides from milk proteins to functionalize fermented milk products. Food Res. Int. 63:71-80.

Miguel, M., M. M. Contreras, I. Recio, and A. Aleixandre. 2009. ACEinhibitory and antihypertensive properties of a bovine casein hydrolysate. Food Chem. 112:211-214.

Moslehishad, M., E. M. Reza, M. Salami, S. Mirdamadi, H. Ezzatpanah, N. A. Niasari, and A. A. Moosavi-Movahedi. 2013. The comparative assessment of ACE-inhibitory and antioxidant activities of peptide fractions obtained from fermented camel and bovine milk by Lactobacillus rhamnosus PTCC 1637. Int. Dairy J. 29:82-87.

Norma Oficial Mexicana. 2012. Official Mexican Norms for dairy products physicochemical analysis: NOM-155-SCFI-2012. Accessed Mar. 12, 2013. http://www.dof.gob.mx/normasOficiales/4692/ seeco/seeco.htm.

Paul, M., and D. L. Van Hekken. 2011. Assessing antihypertensive activity in native and model Queso Fresco cheese. J. Dairy Sci. 94:2280-2284.

Pihlanto, A. 2006. Antioxidative peptides derived from milk proteins. Int. Dairy J. 16:1306-1314.

Pintado, M. E., A. C. Macedo, and F. X. Malcata. 2001. Review: Technology, chemistry and microbiology of whey cheese. Food Sci. Technol. Int. 7:105-116.

Prazeres, A. R., F. Carvalho, and J. Rivas. 2012. Cheese whey management: A review. J. Environ. Manage. 110:48-68.

Re, R., N. Pellegrini, A. Proteggente, A. Panala, M. Yang, and C. Rice-Evans. 1999. Antioxidant activity applying an improved ABTS radical cation decolorization assay. Free Radic. Biol. Med. 26:1231-1237.

Rodríguez-Figueroa, J. C., A. F. González-Córdova, M. J. TorresLlanez, H. S. Garcia, and B. Vallejo-Cordoba. 2012. Novel angiotensin I-converting enzyme inhibitory peptides produced in fermented milk by specific wild Lactococcus lactis strains. J. Dairy Sci. 95:5536-5543.

SIAP-SAGARPA. 2014. Milk bulletin. Servicio de Información Agroalimentaria y Pesquera-Secretaría de Agricultura, Ganadería, Desarrollo Rural, Pesca y Alimentación. Accessed Dec. 16, 2014. http:// www.siap.gob.mx/wp-content/uploads/2013/BoletinLeche/Bolet_ LecheEne-Mar_2014.pdf.

Siso, M. I. G. 1996. The biotechnological utilization of cheese whey: A review. Bioresour. Technol. 57:1-11.

Tavares, T. G., M. M. Contreras, M. Amorim, P. J. Martín-Álvarez, M. E. Pintado, I. Recio, and F. X. Malcata. 2011. Optimisation, by response surface methodology, of degree of hydrolysis and antioxidant and ACE-inhibitory activities of whey protein hydrolysates obtained with cardoon extract. Int. Dairy J. 21:926-933.

Torres-Llanez, M. J., A. F. González-Córdova, A. Hernandez-Mendoza, H. S. Garcia, and B. Vallejo-Cordoba. 2011. Angiotensinconverting enzyme inhibitor activity in Mexican Fresco cheese. J. Dairy Sci. 94:3794-3800.

Udenigwe, C. C., and A. Mohan. 2014. Mechanisms of food proteinderived antihypertensive peptides other than ACE inhibition. J. Funct. Foods 8C:45-52.

USDA-NASS (National Agriculture Statistical Service). 2014. Dairy products. Accessed Mar. 24, 2015. http://www.nass.usda.gov/ Publications/Todays_Reports/reports/dary0514.pdf.

Wu, J., R. E. Aluko, and A. D. Muir. 2002. Improved method for direct high-performance liquid chromatography assay of angiotensin-converting enzyme-catalyzed reactions. J. Chromatogr. A 950:125-130.

Zhu, D., and S. Damodaran. 2012. Annatto in Cheddar cheese-derived whey protein concentrate is primarily associated with milk fat globule membrane. J. Dairy Sci. 95:614-617. 